Article

\title{
How Domestic Firms Benefit from the Presence of Multinational Enterprises: Evidence from Indonesia and Philippines
}

\author{
Joshua Akinlolu Olayinka $₫$ and Sirinuch Loykulnanta * \\ Faculty of Management Sciences, Prince of Songkla University, Songkhla 90110, Thailand; \\ ja.olayinka@gmail.com \\ * Correspondence: sirinuch.1@psu.ac.th; Tel.: +66-74-287-920
}

Received: 3 August 2019; Accepted: 10 September 2019; Published: 16 September 2019

check for updates

\begin{abstract}
Incentives are provided to attract multinational enterprises (MNEs) to host countries, with the expectation that their technology will spread to domestic firms. The purpose of this study is to examine how domestic firms benefit from the spillover of technology from MNEs. Using balanced panel data obtained from the World Bank Enterprise Survey, this study examined the impact of technology spillover through three channels: demonstration, competition, and worker mobility on productivity of domestic firms in Indonesia and Philippines. This study also explored the importance of domestic firms' absorptive capacity in capturing benefits from the three spillover channels. The Cobb-Douglas production model was used as the basis for the estimation model. A fixed-effect model for panel data analysis was used to analyze the data. The empirical outcome of this study revealed that worker mobility is the most viable channel of spillover in the two countries. It also showed that firms with high absorptive capacity were found to benefit from all the channels of spillover in both countries, while the firms with low absorptive capacity benefit differently in the two countries. Thus, this study validates the need for domestic firms to develop absorptive capacity in order to benefit from the technology spillover from MNEs.
\end{abstract}

Keywords: technology spillover; demonstration; competition; worker mobility; absorptive capacity; productivity

\section{Introduction}

Multinational enterprises (MNEs) are both sources of international capital flow and technology (UNCTAD 2010). With the globalization of the world economy and regional economic integration, MNEs continue to expand across countries. MNEs have the tendency to bridge the technology divide between developed and developing countries. MNEs from developed countries are, in fact, the major inventors of new and advanced technology, since they often have the required funds for research and development $(R \& D)$. These technologies are transferred to their affiliates or subsidiaries in the host country, and their subsidiaries then compete with domestic firms, using the advanced technology transferred from their parent company, as their firm-specific competitive advantage. The coexistence of MNEs' subsidiaries and domestic firms in an economy will generate externality in the form of technology spillover from the MNEs to domestic firms, thus improving the efficiency and productivity of the domestic firms (Barrios et al. 2005). Technology spillover is one of the major benefits that domestic firms can gain from the presence of MNEs in their country. According to Romer (1990), technology spillover is the most important channel for the diffusion of modern technology across countries, more so than formal technology transfer transactions. 
This explains why many countries, most especially developing and emerging economies, often have certain incentives to attract multinational companies. The expectation is that MNEs will bring advanced technology to the country, and that the technology will spill over to the domestic firms (Buckley et al. 2010). However, technology spillover has been mostly supported by data from developed countries, rather than developing or emerging countries (Meyer and Sinani 2009). The empirical studies from developing countries have been mostly insignificant or negative (Damijan et al. 2013). The reason for the insignificant result has been identified as the inability of empirical studies to test the channels of spillover, rather than treating spillover as a black box (Ben Hamida 2011; Orlic et al. 2018). Another reason identified in empirical studies that affects technology spillover is the nature of the domestic firms' absorptive capacity (Blalock and Simon 2009; Ha and Giroud 2015). Absorptive capacity is defined as the ability of domestic firms to utilize knowledge acquired from MNEs and increase their application of spillovers (Meyer and Sinani 2009; Narula and Marin 2003). Limited studies have controlled for the heterogeneity of domestic firms' absorptive capacity (Mebratie and Bergeijk 2013). Therefore, the aim of this study is to examine technology spillover through the channels of spillover, and to examine if the presence of MNEs generates a positive spillover effect on the domestic firms at different levels of absorptive capacity.

This study examines and compares technology spillover in Indonesia and the Philippines. Both countries are members of the Association of South East Asia Nations (ASEAN). While Indonesia is the largest economy in the region, Philippines has the fifth largest economy among the ten countries in the region. Due to an increase in policy liberalization, and economic corporation and integration in the region, the two countries have experienced increase in foreign direct investment (FDI) in recent years. Therefore, examining and comparing the technology spillover in those two countries is particularly important for this study.

\section{Literature Review}

\subsection{Theoretical Literature}

The existence of technology spillover is founded upon three logical bases: MNEs own superior technologies; these technologies are transferred to their affiliates or subsidiaries in the host countries; and these technologies spread unintentionally from the affiliates or subsidiaries to the domestic firms in the host countries. These logical bases are explained by the theory of internalization and technology spillover.

\subsubsection{Theory of Internalization}

The theory of internalization was developed by Buckley and Casson (1976); Rugman (1981) and Hennart (1982). According to internalization theory, MNEs exist because of the need to create an internal market for the exploitation of their firm specific advantage (FSA) (Rugman 2006). Since firms are heterogeneous in their internal capacity and production factor endowment (Andrews 1971; Peteraf 1993), firms with superior resources tend to generate a monopoly rent by sustaining the resources within the firm. The superior resources could be better management, production and process technology, skills and know-how. These resources give the firm an advantage over its competitors. Thus, firms with superior resources exploit their advantages across their national borders. The exploitation of the advantages across national borders can be done through exporting their products to another country. It can also be done by licensing their technology to another company in order to generate royalties from the licensees. However, exporting and licensing could lead to the dissipation of the FSA. This is because the ownership of the FSA, which is mostly an intangible proprietary knowledge asset arising from technology, marketing, brand name, capital, access to financing, process efficiencies, size (economies of scale and scope), and managerial expertise (Rugman 1981; Verbeke 2013), is best protected within the management structure of the MNE. Internalization theory therefore states that firms with FSA will exploit their advantages across national boundaries through foreign direct 
investment, rather than through export and licensing, that could dissipate the advantage. In other words, MNEs arise because of the need to keep their FSA within their management structure, as way to prolong the appropriability span of their FSA. This theory, therefore, reveals that parent MNEs send their technology to their subsidiaries to be exploited in a host country market. Internalization theory also explains why the MNEs are constantly doing R\&D. Vernon (1977) argues that the FSA of an MNE is in constant danger of being eroded due the natural product, technology or knowledge lifecycle and that MNEs need to generate new advantages to overcome the gradual decline in value. Due to this dynamic nature of knowledge, MNEs need to constantly research and develop new knowledge and market it efficiently internally among its subsidiaries, in order to sustain its competitive advantage. Put simply, the theory of internalization explains that MNEs are firms that have non-location bound FSA, and that chose to exploit their technological advantages through their subsidiaries, rather than through exporting or licensing, as a way of protecting their FSA and prolonging its appropriability span. This theory, therefore, suggests that MNEs possess higher than normal FSA, which they transfer it to their subsidiaries.

\subsubsection{Technology Spillover}

Technology spillover arises because it is impossible for MNEs' subsidiaries to completely internalize the benefit of their advanced technology (Keller 2004). The use of advanced technology by MNEs generates externalities in certain ways. The technologies of the MNEs can spill over to domestic firms when the domestic firms observe the technology used by the MNEs, known as the demonstration effect (Blomström and Kokko 1998; Findlay 1978). Moreover, the presence of MNEs increases the competition and forces the domestic firm to adopt better technology, known as the competition effect (Kokko 1996; Wang and Blomström 1992). Also, staff previously employed by MNEs can be employed by domestic firms, known as worker mobility (Fosfuri et al. 2001; Glass and Saggi 2002). The technology spillover from MNEs to domestic firms, therefore, results in improvement of productivity of domestic firms in the host country. The channels, through which technology spillovers occur, are illustrated in Figure 1.

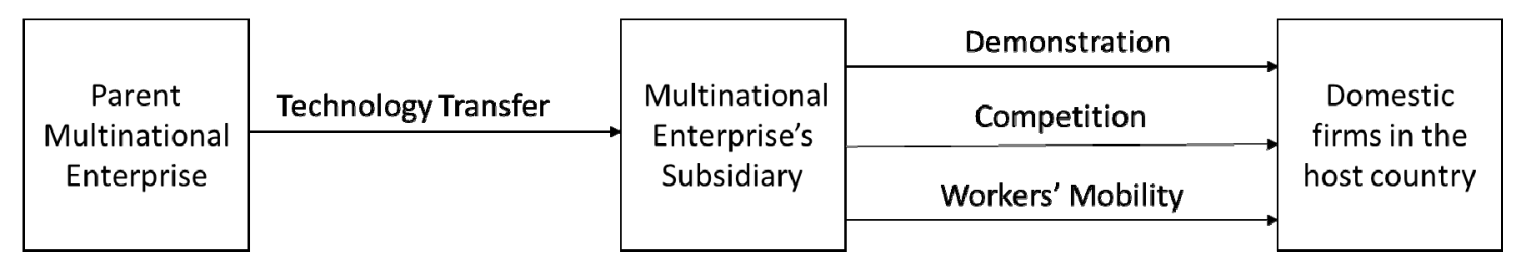

Figure 1. Channels of technology spillover.

\subsubsection{Technology Spillover through Demonstration Effect}

When MNEs enter a new market, they demonstrate their advance technology in terms of production, process, quality control, distribution systems, and organization (Blomström and Kokko 2002; Sönmez 2013). The advanced technology of MNEs is displayed in their improved products and services. Domestic firms can increase their efficiency and productivity by imitating or doing reverse engineering of the technologies used by MNEs. Moreover, domestic firms can set their benchmarks against MNEs, and can observe new and improved technology that MNEs introduce into the industry.

However, Meyer and Sinani (2009) have stated that technology can easily be observed if it is non-proprietary, and that MNEs have the incentive to increase their measures to prevent spillover, once they view local firms as competitors rather than as needy recipients of development aid. Moreover, the scope of this imitation depends on the complexity of the technological products and processes (Görg and Greenaway 2004), and according to Ivus et al. (2017), imitation is low in high technology industries, due to the technological complexity of the products. 


\subsubsection{Technology Spillover through Competition Effect}

The entrance of MNEs increases the competition for domestic firms in the host country. MNEs increase the competition by increasing the number of competitors, that is, quantity of competition, and by using superior technology, that is, the quality of competition (Driffield and Love 2007). This competition forces domestic firms to use their existing technology more efficiently, or to upgrade their technology to be competitive and protect their market share (Sönmez 2013; Wang and Blomström 1992). Thus, competition will in effect increase the productivity of the domestic firms. This competition effect suggests that the technological or productivity improvement of the domestic firms is partly endogenous in nature, even though it is motivated by the increased competition created by the entrance of MNEs in the industry.

However, Aitken and Harrison (1999) have stated that the entrance of MNEs may negatively affect the productivity of the domestic firms. Since MNEs are market-oriented and often use superior technology, they can lower their marginal cost and product price, thereby drawing demand away from domestic firms. This will force domestic firms to cut production as they lose more market share to MNEs. This is known as market stealing or the crowding out effect (Aitken and Harrison 1999; Meyer and Sinani 2009).

\subsubsection{Technology Spillover through Worker Mobility}

Another channel through which technology from MNEs can spill over to domestic firms is through worker mobility. This is when workers previously employed by MNEs are recruited by domestic firms. According to Sönmez (2013), workers employed by MNEs gain knowledge of its technology through training and experience, and will transfer this knowledge to the domestic firms if employed by them. This is because technology has both explicit and tacit components (Keller 2004). The explicit component is coded and transferrable through machinery, blueprints, technical manuals, training hand-outs, technical specifications and quality control methods (Kim 2001). The tacit component (also referred to as practical knowledge or know-how), conversely, is not codified, and rather, is embodied in the workers' experience and skill (Keller 2004; Sönmez 2013). Therefore, skills and technological knowledge of the domestic workers previously employed and trained by MNEs may spill over to domestic firms when they are hired by domestic firms in the host country.

MNEs, however have the incentive to prevent this kind of spillover by paying higher wages, so as to prevent employee turnover. It should therefore be noted that this channel may also have a negative impact on domestic firms, as MNEs may attract skilled workers away from domestic firms by offering higher wages, or by increasing the average wage demanded by workers in the industry.

\subsubsection{Absorptive Capacity}

Absorptive capacity is defined as the ability of domestic firms to utilize knowledge acquired from MNEs and increase their realized spillovers (Cohen and Levinthal 1990; Meyer and Sinani 2009; Narula and Marin 2003). This involves the ability of the domestic firms to recognize valuable new knowledge, adopt and adapt it for their own productive use. In theoretical literature, absorptive capacity is also referred to as the technological gap between the source and the recipient in terms of technological competence (Borensztein et al. 1998; Xu 2000). A wide technological gap between the source of spillover and the recipient will indicate low absorptive capacity. According to Ben Hamida (2011), domestic firms must possess sufficient levels of absorptive capacity to be able to efficiently take advantage of technology spillovers. Furthermore, domestic firms must have some level of technological knowledge to be able to assimilate advanced technology. Developing absorptive capacity is a function of the firms' own R\&D. As firms invest in R\&D to develop new technology, they also develop their ability to assimilate technology from other firms (Narula and Marin 2003). 


\subsection{Empirical Review}

Studies on technology spillover in developing countries have used a range of methodologies and measurements, and have generally found insignificant or negative effects on the productivity of domestic firms (Damijan et al. 2003). Typically, a measure of the presence of MNEs is included in a production function, with the productivity of the domestic firms as the dependent variable (Keller 2004). The proxies for the presence of MNEs used in past studies have been the share of industry sales, employment, and capital accounted for by MNEs. For instance, Le and Pomfret (2011) investigated technology spillover from FDI in Vietnam. They measured spillover as the share of employment by foreign firms in the industry and found that it had a negative effect on the productivity of domestic firms. However, as noted by Ben Hamida (2011) these proxies do not sufficiently capture other channels of spillover. This is a major drawback of previous research. Thus, Ben Hamida (2011) proposed breaking down the channels of spillover in assessing the benefit of spillover. Accordingly, recent studies have separated the effects of the different channels on the productivity of the domestic firms.

Jude (2016) examined the intensity of the different channels of spillover in Romania. Using an unbalanced firm-level panel data of 3500 firms from 1999 to 2007 obtained from Amadeus database, a pan-European database, she found that the pressure from the competition effect did not seem intense and had no significant effect on the productivity of the domestic firms. Spillover through demonstration was also not strong enough to generate gains in productivity for domestic firms. However, technology spillover through worker mobility was found to enhance the productivity of the domestic firms in Romania. These findings emphasize the importance of examining different channels of technology spillover.

Orlic et al. (2018) studied technology spillover in five European transition countries, namely Czech Republic, Estonia, Hungary, Slovakia and Slovenia. They examined the effects of technology spillover through each of the three channels separately. They used panel data from 2002 to 2010 obtained from the Amadeus database. The findings from the five countries varied, but largely supported worker mobility as the strongest channel of technology spillover. Demonstration effect had a negative impact on the productivity of the domestic firms in all countries, except for Slovenia, where it had no significant effect. The competition effect had a negative impact on the productivity of domestic firms in Czech Republic, Hungary, and Slovakia, but it had a positive impact in Estonia and no significant effect in Slovenia. Conversely, worker mobility had a positive impact in Czech Republic, Estonia, Hungary, and Slovakia, but no significant effect in Slovenia.

Based on the empirical literature reviewed, although conducted in European transition countries, the evidence abounds that worker mobility is the most viable channel of spillover of technology from MNEs to domestic firms. In the context of Indonesia and Philippines, which are developing countries in Southeast Asia, it is expected that the result will be broadly similar. Spillover through demonstration and competition may generate limited spillover to domestic firms in these developing countries. This is because these channels of spillover often require a certain level of absorptive or technology capacity to be able to copy and compete with the advanced technology of MNEs. The technology capacity may be lacking in domestic firms of developing countries, due to the large technology divide between developed and developing countries. Hiring workers who have previously worked with MNEs, on the other hand, increases the certainty of spillover and therefore, appears to be an effective alternative for domestic firms actively seeking technology spillover. Moreover, this channel provides assistance (technical, managerial, etc.) which can help domestic firms to better understand and implement the foreign technology. Hence, we assert the following main hypothesis:

Hypothesis 1. Spillover occurs largely through worker mobility, whereas demonstration and competition are less important.

Absorptive capacity or the technology gap can also affect the channel of technology spillover. Ben Hamida (2011) found, from the Swiss service and construction industry, that domestic firms 
with high technological capacities gain spillover benefit from the increased competition from MNEs, while mid and low technology firms benefit from the demonstration effects. As stated by Sönmez (2013), relatively high technology firms are significantly more likely to benefit from spillovers through demonstration and/or competition effects, while low-technology firms, which are not in a position to compete with foreign firms, gain more from other forms of spillovers, such as worker mobility. Therefore, we hypothesize that:

Hypothesis 2. The level of absorptive capacity of a firm affects the relative significance of the channels of technology spillover.

\section{Methodology}

\subsection{Data}

This study used firm-level balanced panel data obtained from the World Bank Enterprise Survey. The World Bank Enterprise Survey is a firm-level survey of the manufacturing and service firms for 139 countries. The Enterprise Survey used stratified random sampling method. The firms were surveyed in 2009 and 2015 for both Indonesia and Philippines. The survey was not conducted annually, and hence, the gap in years. Previous studies, such as Ben Hamida (2011), used innovation activity surveys obtained in 2002 and 2005 as panel data for the empirical study of technology spillover in Switzerland. Driffield (2001) used data obtained from the UK Office of National Statistics in 1989 and 1992 to test the impact of foreign direct investment (FDI) on domestic productivity. Demena and Murshed (2018) used World Bank Enterprise Survey data for 2006 and 2014 to examine technology spillover in eight sub-Saharan Africa countries. According to Duncan (2015), a panel data may differ in the interval between rounds of data collection and the length of the survey. A panel survey could be conducted daily, weekly, biweekly, monthly, quarterly, biannually, and more or less frequently (Duncan 2015). As shown in Table 1, our data initially contained 2042 and 2080 observations for Indonesia and Philippines. Firms with important missing information were removed, the variables were calculated, outliers were removed, and balanced panel data was extracted. This, therefore, provided a balanced data panel of 546 and 518 for Indonesia and Philippines, respectively, for analysis.

Table 1. Data Information.

\begin{tabular}{cccc}
\hline Country & Data Years & All & Panel \\
\hline Indonesia & $2009 / 2015$ & 2042 & 546 \\
Philippines & $2009 / 2015$ & 2080 & 518 \\
\hline
\end{tabular}

\subsection{Model Estimation}

The technology spillover effect on the productivity of domestic firms for this study is modeled within the context of the Cobb-Douglas production function, as stated below:

$$
\text { Yijt }=A_{i j t} L_{i j t}^{\beta 1} K_{i j t} \beta 2
$$

The output $\mathrm{Y}$ of a domestic firm (i) in industry (j) at time (t) is a function of the inputs, labor (L) and capital (K). The level of productivity is given by Aijt, which is assumed to vary across firms within each industry and across time. A number of previous studies such as Aitken and Harrison (1999); Tian (2007); Zhang et al. (2010); and Ben Hamida (2011) had also based their empirical estimation on the Cobb-Douglas production function. The linearized equation of the Cobb-Douglas production function is presented below:

$$
\ln \left(\mathrm{Y}_{\mathrm{ijt}}\right)=\ln \left(\mathrm{A}_{\mathrm{ijt}}\right)+\beta_{1} \ln \left(\mathrm{L}_{\mathrm{ijt}}\right)+\beta_{2} \ln \left(\mathrm{K}_{\mathrm{ijt}}\right)+\mathrm{e}_{\mathrm{ijt}}
$$


The stochastic disturbance term (e) is introduced in the equation. Most empirical studies have proxy A to be the presence of MNEs in the industry, and the control for firm size and industry type. However, this research separates the effects from the different channels of horizontal technology spillover. Proxies for technology spillover through demonstration, competition, and worker mobility are introduced to represent the level of productivity while controlling for the effect of differences in industry. The measurement and the proxies are discussed further in the variable measurement section.

$$
\ln \left(\mathrm{A}_{\mathrm{ijt}}\right)=\beta_{3} \mathrm{FP}_{\mathrm{jt}}+\beta_{4} \operatorname{Comp}_{\mathrm{jt}}+\beta_{5} \mathrm{FP}_{\mathrm{jt}}{ }^{*} \mathrm{HC}_{\mathrm{ijt}}+\beta_{6} \text { Industry }_{\mathrm{ij}}
$$

$\mathrm{FP}=$ foreign presence, which is the measure of demonstration effect

$\mathrm{HC}=$ Human capital

Comp = Competition effect

When Equation (3) is combined with Equation (2) it becomes the final linear equation below:

$$
\ln \left(\mathrm{Y}_{\mathrm{ijt}}\right)=\alpha_{0}+\beta_{1} \ln \left(\mathrm{L}_{\mathrm{ijt}}\right)+\beta_{2} \ln \left(\mathrm{K}_{\mathrm{ijt}}\right)+\beta_{3} \mathrm{FP}_{\mathrm{jt}}+\beta_{4} \operatorname{Comp}_{\mathrm{jt}}+\beta_{5} \mathrm{FP}_{\mathrm{jt}}{ }^{*} \mathrm{HC}_{\mathrm{ijt}}+\beta_{6} \operatorname{Industry}_{\mathrm{ij}}+\mathrm{e}_{\mathrm{ijt}}
$$

\subsection{Variables Measurement}

The dependent variable, which is the output of the domestic firm $\mathrm{Y}$, is proxy by value added of the domestic firm, consistent with Kokko (1996); and Blomström and Sjöholm (1999). The value added is calculated as sales less cost of raw materials and finished product bought for resale. This is appropriate for this study, because the firms include both manufacturing and service providing firms. The service providing firms have no tangible output, thus value added is the uniform measure of output for both the manufacturing and service firms. Domestic firms' value added was, however, corrected for inflation by dividing with the country's GDP deflator for the years in the study.

The independent variables for this study are technology spillover through demonstration, technology spillover through competition, and technology spillover through worker mobility. The control variables are labor, capital and industry.

Technology spillover through demonstration is represented in Equation (4) as foreign presence (FP) and it is measured as the share of sales by foreign firms or MNEs in the industry. This is consistent with the measurement of foreign presence by Kathuria (2000). The share of sale is likely to show demonstration effect, because domestic firm can observe the product sold by MNEs and copy or reverse engineer it. According to IMF (2009), the direct investment in a foreign market could be at least ten percent equity in another company abroad. Therefore, a MNE is defined as an enterprise that has at least ten percent ownership in another firm outside its national boundary.

Technology spillover through competition is represented by Comp in Equation (4). Following Orlic et al. (2018), this study used the Herfindahl-Hirschman Index (HHI). The HHI is degree of market concentration in an industry (Rhoades 1993). The HHI is calculated by squaring the market share of the firms in the industry, thus giving more value to firms with a higher market share. A monopolistic industry with just one firm will have an index value of 1 . This means that the market concentration of the firm is high. However, in this study, competition is measured as one minus HHI. Thus, a monopolistic industry will have the competition value of zero, indicating no competition in the industry. A lower the $\mathrm{HHI}$ indicates higher competition. This is because $\mathrm{HHI}$ measures the market concentration and the higher the value, the higher the concentration, and thus, the lower the market competition.

Technology spillover through worker mobility is represented by the interaction term $\mathrm{FP}^{*} \mathrm{HC}$ between the share of foreign presence and the firm's human capital. This interaction between foreign presence and human capital has been used as the proxy for worker mobility in studies by Ben Hamida (2011); Demena and Murshed (2018) and Orlic et al. (2018). The interaction term measures the combined effect of the presence of foreign firms in an industry and level of human capital on domestic firms' productivity. Worker mobility is assumed to be co-determined by the two variables, where, HC is measured as average labor cost for the individual firm, consistent with Ben Hamida (2011). 
The two variables used in the interaction term were centered by subtracting the full sample mean (Aiken et al. 1991) to prevent multicollinearity between worker mobility and demonstration effect.

To test the second hypothesis, domestic firms in the two countries were divided into firms with high absorptive capacity and low absorptive capacity, and the effect of the independent variables on the dependent variable was examined again. The absorptive capacity was measured by the ratio of average labor productivity of the MNEs in the industry to the domestic firms' labor productivity, consistent with Ben Hamida (2011) and Demena and Murshed (2018). A lower ratio corresponds with high absorptive capacity of a domestic firm. A value of one indicates the same level of labor productivity between the individual domestic firms and the industry technological frontiers (MNEs). Domestic firms were then categorized as having high absorptive capacity when the value was below or equal to one, while firms with value higher than one were categorized as low absorptive capacity. Domestic firms' absorptive capacity in the first year of study, 2009, was used as the proxy. It was expected that firms with high absorptive capacity in the first years will benefit more from spillover in the subsequent years. Labor productivity used in computing absorptive capacity was measured as value added per employee.

The domestic firm input labor (L) is measured as the number of employees of firm (i) at industry (j) and across time (t). The capital (K) is measured net book value of the physical asset of firm (i) at industry (j) and across time ( $\mathrm{t})$. Industry is a nominal variable and is represented by the four-digit United Nations' International Standard Industry Classification of all Economic Activities (ISIC) forth revision. The four-digit ISIC code is given to the firms based on the major product or service of the firms. In line with the developed estimation model, the logarithms of the dependent variable value added, and that of control variables labor and capital, were taken.

\subsection{Data Analysis}

The data was tested for multicollinearity with both Pearson correlation and variance inflation factor (VIF). Both data from Indonesia and Philippines showed no sign of multicollinearity. In addition to multivariate normality using normal probability plots, White's test for heteroskedasticity and the Wooldridge test for autocorrelation were also conducted and any problem identified was corrected to ensure the reliability of estimation. To select the best empirical estimation technique for the panel data, certain econometric tests were conducted. First, we conducted the Breusch-Pagan Langrange multiplier (BP-LM) test. The BP-LM test was significant, therefore the use of pooled ordinary least squares (OLS) regression was rejected. The Hausman test was conducted and the result was significant, thus suggesting that the fixed-effect model is the efficient estimation method for the data set of each country, rather than the random-effect model. Therefore, data for both Indonesia and Philippines were analyzed using the fixed-effect model. The fixed-effect model assumes that the individual specific effects are correlated with the independent variables, controls for the effect from the individual specific effects, and provides the net effect of the independent variables (Thi Ngoc Huynh et al. 2018).

\section{Empirical Results}

Tables 2 and 3 below presents the descriptive statistics of the variables in the form of mean and standard deviation for Indonesia and Philippines. Pearson correlations among the variables are also presented. In the two countries, the control variables, labor and capital, were positively correlated to the dependent variable, value added. Similarity was also found in the result of the two countries, with technology spillover through demonstration and worker mobility having positive correlations with the dependent variable at $99 \%$ confidence intervals. However, competition showed no significant correlation with the dependent variable. In Indonesia, the largest correlation was found between labor and capital with correlation coefficient $(\mathrm{r}=0.57, p<0.01)$. On the other hand, in Philippines, the largest significant correlation was between value added and capital with correlation coefficient $(r=0.51, p<0.01)$. In both data sets, there was no evidence of multicollinearity because the correlation coefficient was below 0.7 (Tabachnick and Fidell 2007). 
Table 2. Descriptive Statistics for Indonesia.

\begin{tabular}{ccccccccc}
\hline Variables & Mean & SD & Labor & Capital & Demonstration & Competition & Worker Mobility & Value Added \\
\hline Labor & 1.58 & 0.75 & 1.00 & & & & & \\
Capital & 8.72 & 1.31 & $0.57^{* *}$ & 1.00 & & & & \\
Demonstration & 0.57 & 0.34 & $0.18^{* *}$ & $0.17^{* *}$ & 1.00 & & & \\
Competition & 0.54 & 0.30 & 0.05 & 0.03 & $0.09^{*}$ & 1.00 & 1.00 & 1.00 \\
Worker mobility & 8.38 & 1.22 & $0.09^{*}$ & $0.11^{*}$ & $0.56^{* *}$ & $0.24^{* *}$ & $0.15^{* *}$ & 0.03 \\
Value Added & 9.21 & 1.32 & $0.55^{* *}$ & $0.43^{* *}$ & $0.16^{* *}$ & 0.01, SD (Standard deviation).
\end{tabular}

Table 3. Descriptive Statistics for Indonesia.

\begin{tabular}{|c|c|c|c|c|c|c|c|c|}
\hline Variables & Mean & SD & Labor & Capital & Demonstration & Competition & Worker Mobility & Value Added \\
\hline Labor & 1.64 & 0.57 & 1.00 & & & & & \\
\hline Capital & 7.17 & 1.07 & $0.49^{*}$ & 1.00 & & & & \\
\hline Demonstration & 0.36 & 0.37 & $0.12 *$ & 0.05 & 1.00 & & & \\
\hline Competition & 0.68 & 0.27 & 0.02 & 0.004 & $-0.42 *$ & 1.00 & & \\
\hline Worker mobility & 4.28 & 1.10 & 0.64 & $0.33 *$ & $0.44 *$ & $-0.27 *$ & 1.00 & \\
\hline Value Added & 5.31 & 1.05 & $0.50 *$ & $0.51 *$ & $0.12 *$ & -0.06 & 0.38 * & 1.00 \\
\hline
\end{tabular}

Table 4 below reveals the results of the fixed effect model estimate for both Indonesia and Philippines. Labor and capital had a positive impact on value added of domestic firms in both countries, supporting the assumptions of Cobb-Douglas production function. In terms of the channels of technology spillover, in Indonesia, spillover from demonstration positively influenced the productivity of the domestic firms at $\beta=0.015(p<0.01)$. Additionally, spillover from worker mobility positively influenced the productivity of the domestic firms at $\beta=0.619(p<0.01)$. On the other hand, competition had a negative influence on the productivity of the domestic firms, at $\beta=-0.195$ $(p<0.05)$. In Philippines, technology spillover through demonstration did not significantly influence the productivity of the domestic firms. Competition, also, had a negative influence on the productivity of the domestic firms at $\beta=-0.058(p<0.05)$. However, worker mobility had a positive influence of the productivity of domestic firms at $\beta=0.270(p<0.01)$. In both countries, spillover from the worker mobility channel provided the strongest positive influence on the productivity of the domestic firm when compared to the other two channels. The model for Indonesia explained about $66.7 \%$ of the variation in domestic firms' productivity, while the model for Philippines explained about $59.2 \%$ of the variation in productivity of domestic firms.

Table 4. Results of fixed effect model estimate (Full samples).

\begin{tabular}{ccc}
\hline Variables & Indonesia & Philippines \\
\hline Labor & $0.883^{* *}(0.174)$ & $0.394^{* *}(0.130)$ \\
Capital & $0.070^{* *}(0.016)$ & $0.263^{* *}(0.057)$ \\
Demonstration & $0.015^{* *}(0.002)$ & $0.269(0.186)$ \\
Competition & $-0.195^{*}(0.099)$ & $-0.058^{*}(0.029)$ \\
Worker mobility & $0.619^{* *}(0.063)$ & $0.270^{* *}(0.076)$ \\
Industry & $-0.000(0.000)$ & $-0.000(0.001)$ \\
Constant & $3.308^{* *}(0.664)$ & $2.019^{* *}(0.509)$ \\
$\mathrm{R}^{2}$ & 0.667 & 0.592 \\
$\mathrm{~N}$ & 546 & 514 \\
\hline
\end{tabular}

Note: ${ }^{* *} p<0.01, * p<0.05 . \mathrm{N}$ is the number of observations. Standard error is presented in the parenthesis. Hausman test for Indonesia was $12.86(p=0.046)$ while for Philippines was $20.81(p=0.002)$.

\section{Spillover and Absorptive Capacity}

Firms with high absorptive capacity in 2009 were separated from firms with low absorptive capacity and the empirical model was tested again. The results are presented in Table 5 below. The effect of the labor and capital remained positive to value added of the domestic firms, in support of the 
assumptions of the Cobb-Douglas production function. In terms of the channels of spillover, domestic firms with a high absorptive capacity in both countries benefitted from all channels of technology spillover. Furthermore, the results showed that for both countries, spillover through worker mobility was the strongest channel of spillover among domestic firms with high absorptive capacity. However, the results for domestic firms with low absorptive capacity were different.

In Indonesia, domestic firms with low absorptive capacity benefitted from both spillover through demonstration and worker mobility. Demonstration had a positive influence on the productivity of domestic firms at $\beta=0.014(p<0.01)$. Worker mobility positively impacted the productivity of domestic firms at $\beta=0.635(p<0.01)$. However, competition had a negative influence on the productivity of domestic firms at $\beta=-0.295(p<0.01)$. In Philippines, demonstration had no significant effect on the productivity of domestic firms. Worker mobility positively impacted the productivity of domestic firms at $\beta=0.182(p<0.05)$. Competition, on the other hand, negatively impacted the productivity of domestic firms at $\beta=-0.151(p<0.05)$. The effects of worker mobility and competition on productivity of domestic firms with low absorption capacity were similar in both countries.

Table 5. Results of fixed effect model at different absorptive capacity.

\begin{tabular}{ccccc}
\hline \multirow{2}{*}{ Variables } & \multicolumn{2}{c}{ Indonesia } & \multicolumn{2}{c}{ Philippines } \\
\cline { 2 - 5 } & $\begin{array}{c}\text { High Absorptive } \\
\text { Capacity }\end{array}$ & $\begin{array}{c}\text { Low Absorptive } \\
\text { Capacity }\end{array}$ & $\begin{array}{c}\text { High Absorptive } \\
\text { Capacity }\end{array}$ & $\begin{array}{c}\text { Low Absorptive } \\
\text { Capacity }\end{array}$ \\
\hline Labor & $0.291^{* *}(0.081)$ & $0.909^{* *}(0.157)$ & $0.774^{* *}(0.109)$ & $0.302^{*}(0.149)$ \\
Capital & $0.055^{* *}(0.016)$ & $0.048^{*}(0.016)$ & $0.329^{* *}(0.061)$ & $0.316^{* *}(0.080)$ \\
Demonstration & $0.021^{*}(0.009)$ & $0.014^{* *}(0.002)$ & $0.206^{*}(0.097)$ & $0.431(0.342)$ \\
Competition & $0.032^{*}(0.015)$ & $-0.295^{*}(0.139)$ & $0.105^{*}(0.051)$ & $-0.151^{*}(0.077)$ \\
Worker mobility & $0.592^{*}(0.239)$ & $0.635^{* *}(0.063)$ & $0.231^{* *}(0.064)$ & $0.182^{*}(0.074)$ \\
Industry & $0.0001(0.0005)$ & $-0.0001(0.001)$ & $0.0007(0.0005)$ & $-0.0000(0.0002)$ \\
Constant & $4.759^{*}(2.163)$ & $2.869^{* *}(0.666)$ & $0.963 *(0.444)$ & $1.743 *(0.741)$ \\
$\mathrm{R}^{2}$ & 0.257 & 0.713 & 0.585 & 0.548 \\
$\mathrm{~N}$ & 84 & 462 & 204 & 314 \\
\hline
\end{tabular}

Note: ${ }^{* *} p<0.01,{ }^{*} p<0.05 . \mathrm{N}$ is the number of observations. Standard error is presented in the parenthesis.

In comparative context, a similar pattern of spillover was found in the two countries, with worker mobility having the strongest positive impact on the productivity of domestic firms. Also, in general, competition mainly affected the productivity of the domestic firms in a negative manner. In both countries, firms with high absorptive capacity benefitted from all channels of spillover. The difference was observed in demonstration having a positive impact in Indonesia and not having any effect in Philippines. This outcome from demonstration was also repeated in domestic firms with low absorptive capacity. These results are discussed further in the following section.

\section{Conclusions and Discussion}

\subsection{Main Findings and Discussion}

One of the main findings of this study is that, without considering the heterogeneity or the nature of the absorptive capacity of the domestic firms, technology spillover from MNEs in Indonesia and Philippines occurs largely through the worker mobility channel. These findings are consistent with the results of Jude (2016) and Orlic et al. (2018). This implies that the form of technology that easily spills over is the tacit component of technological knowledge and is capable of increasing the productivity of domestic firms. This result also suggests that, although the movement of workers from MNEs to domestic firms often requires the payment of a wage premium, the wage premium is not, however, higher than the cost of training employees internally. Therefore, the productivity gains from hiring staff who have previously worked with MNEs more than compensates for the wage premium paid to those staff. Furthermore, technology spillover through demonstration positively influences the 
productivity of domestic firms in Indonesia. This means that domestic firms are able to observe and adopt the technology of MNEs. However, spillover through demonstration is not enough to influence productivity in Philippines. The difference in the result may be attributed to differences in the quantity of FDI inflow to the two countries. Indonesia, which is the largest economy, had an average of $\$ 16,328$ million inflow of FDI from 2009 to 2015 while Philippines had \$2827 million (UNCTAD 2018). Differences in the presence of MNEs in the countries will contribute to the difference in the abundance of MNEs technology to observe. Competition from MNEs negatively impacts the productivity of domestic firms in both countries. This means that MNEs have a market stealing effect on domestic firms. This further supports previous studies that have stated that MNEs have competitive advantages over the domestic firms due to their firm specific proprietary asset, which they can exploit in competing with domestic firms (Mauri et al. 2016).

The results also revealed that firms with different levels of absorptive capacity benefit differently from the channels of technology spillover. Domestic firms with a high absorptive capacity are able to capture benefits from all three channels of spillover. This underscores the importance of absorptive capacity to identify, assimilate, adopt and adapt advanced technology (Narula and Marin 2003). Domestic firms with low absorptive capacity largely benefit from worker mobility. This is consistent with the finding of Sönmez (2013) and it confirms that worker mobility is a viable spillover channel, both for firms with low and high absorptive capacity. Competition from MNEs, however, negatively affects the productivity of domestic firms with low absorptive capacity. This is because firms with low absorptive capacity have little technological strength to compete with MNEs and they are the worst affected in the fight for market share. This can lead to the crowding out of such domestic firms (Aitken and Harrison 1999), due to their weak competitiveness. In summary, therefore, these results revealed that worker mobility is the most important channel of technology spillover and that the level of domestic firms' absorptive capacity affects the significance of channels of spillover. These results, thus, support the two hypotheses earlier proposed in this study.

\subsection{Recommendations}

The empirical results of this study suggest two recommendations, from a managerial perspective. The outcome indicates worker mobility as the most viable channel of spillover, regardless of the technological capacity of the benefiting firm. Therefore, managers of domestic firms need to look beyond the cost of the wage premium they have to pay in recruiting employees who have previously worked with MNEs or even domestic firms with superior technology. This is because gain in productivity will, in the long run, compensate for the increase in human capital expenditure. Second, the results reveal that absorptive capacity is important for benefitting from all channels of spillover. Thus, managers should invest in R\&D which has been identified in past literature as being capable of increasing firms' absorptive capacity.

The policy recommendation on the part of the government, however, is that policy makers should encourage the inflow of more knowledge from MNEs, since the tacit knowledge of the firms can easily spillover to the domestic firms. The government should promote R\&D spending that has the potential to increase the absorptive capacity of the domestic firms and their productivity.

\subsection{Limitations}

This study did not explore inter-industry spillover channels which occur through linkages between domestic firms and MNEs, due to data constraints. Input-output information, which can be used to trace linkages across industries, and is mostly used as the proxy for inter-industry spillovers in empirical literature, is not available to the authors. Hence, it is recommended that future studies should explore inter-industry spillover channels when drawing comparisons between Indonesia and Philippines, or other developing countries. Additionally, data used for this study were collected in 2009 and 2015, which is the latest data for Indonesia and Philippines, as available in January 2019 from the World Bank Enterprise Survey. 
Author Contributions: The authors have contributed equally to the conceptualization, research design, and data analysis. Conceptualization, J.A.O.; Data curation, J.A.O.; Formal analysis, J.A.O.; Methodology, S.L.; Supervision, S.L.; Validation, S.L. The authors have read and approved the final manuscript.

Funding: This research received no external funding.

Acknowledgments: This work was supported by the Higher Education Research Promotion and Thailand's Education Hub for Southern Region of Asian Countries Project Office of the Higher Education Commission (contract number-THE-AC 060/2017). We acknowledge the insightful comments by the anonymous reviewers.

Conflicts of Interest: The authors declare no conflict of interest.

\section{References}

Aiken, Leona S., Stephen G. West, and Raymond R. Reno. 1991. Multiple Regression: Testing and Interpreting Interactions. Thousand Oaks: Sage.

Aitken, Brian J., and Ann E. Harrison. 1999. Do domestic firms benefit from direct foreign investment? Evidence from Venezuela. American Economic Review 89: 605-18. [CrossRef]

Andrews, Kenneth Richmond. 1971. The Concept of Corporate Strategy. New York: Dow Jones-Irwin.

Barrios, Salvador, Holger Görg, and Eric Strobl. 2005. Foreign direct investment, competition and industrial development in the host country. European Economic Review 49: 1761-84. [CrossRef]

Ben Hamida, Lamia. 2011. FDI and spillovers in the Swiss services/construction industry: Interaction effects between spillover mechanisms and domestic technological characteristics. Critical Perspectives on International Business 7: 224-49. [CrossRef]

Blalock, Garrick, and Daniel H. Simon. 2009. Do all firms benefit equally from downstream FDI? The moderating effect of local suppliers' capabilities on productivity gains. Journal of International Business Studies 40: 1095-112. [CrossRef]

Blomström, Magnus, and Ari Kokko. 1998. Multinational corporations and spillovers. Journal of Economic Surveys 12: 247-77. [CrossRef]

Blomström, Magnus, and Fredrik Sjöholm. 1999. Technology transfer and spillovers: Does local participation with multinationals matter? European Economic Review 43: 915-23. [CrossRef]

Blomström, Magnus, and Ari Kokko. 2002. FDI and Human Capital: A Research Agenda. Paris: OECD Development Centre, vol. 3.

Borensztein, Eduardo, Jose De Gregorio, and Jong-Wha Lee. 1998. How does foreign direct investment affect economic growth? Journal of International Economics 45: 115-35. [CrossRef]

Buckley, Peter, and Mark Casson. 1976. The future of the multinational corporation. Journal of International Business Studies 34: 219-22. [CrossRef]

Buckley, Peter J., Jeremy Clegg, and Chengqi Wang. 2010. Is the relationship between inward FDI and spillover effects linear? An empirical examination of the case of China. In Foreign Direct Investment, China and the World Economy. Berlin/Heidelberg: Springer, pp. 192-215.

Cohen, Wesley M., and Daniel A. Levinthal. 1990. Absorptive capacity: A new perspective on learning and innovation. Administrative Science Quarterly 35: 128-52. [CrossRef]

Damijan, Joze P., Mark Knell, Boris Majcen, and Matija Rojec. 2003. Technology Transfer through FDI in Top-10 Transition Countries: How Important are Direct Effects, Horizontal and Vertical Spillovers? Working Paper 549. Ann Arbor: The William Davidson Institute.

Damijan, Jože P., Matija Rojec, Boris Majcen, and Mark Knell. 2013. Impact of firm heterogeneity on direct and spillover effects of FDI: Micro-evidence from ten transition countries. Journal of Comparative Economics 41: 895-922. [CrossRef]

Demena, Binyam Afewerk, and Syed Mansoob Murshed. 2018. Transmission channels matter: Identifying spillovers from FDI. The Journal of International Trade Economic Development 27: 701-28. [CrossRef]

Driffield, Nigel, and James H. Love. 2007. Linking FDI motivation and host economy productivity effects: Conceptual and empirical analysis. Journal of International Business Studies 38: 460-73. [CrossRef]

Driffield, Nigel. 2001. The impact on domestic productivity of inward investment in the UK. The Manchester School 69: 103-19. [CrossRef]

Duncan, Greg J. 2015. Panel surveys: Uses and applications. In International Encyclopedia of the Social E Behavioral Sciences, 2nd ed. Edited by Wright D. James. Oxford: Elsevier, pp. 462-67. 
Findlay, Ronald. 1978. Relative backwardness, direct foreign investment, and the transfer of technology: A simple dynamic model. The Quarterly Journal of Economics 92: 1-16. [CrossRef]

Fosfuri, Andrea, Massimo Motta, and Thomas Rønde. 2001. Foreign direct investment and spillovers through workers' mobility. Journal of International Economics 53: 205-22. [CrossRef]

Glass, Amy Jocelyn, and Kamal Saggi. 2002. Multinational firms and technology transfer. Scandinavian Journal of Economics 104: 495-513. [CrossRef]

Görg, Holger, and David Greenaway. 2004. Much ado about nothing? Do domestic firms really benefit from foreign direct investment? The World Bank Research Observer 19: 171-97. [CrossRef]

$\mathrm{Ha}$, Yoo Jung, and Axèle Giroud. 2015. Competence-creating subsidiaries and FDI technology spillovers. International Business Review 24: 605-14. [CrossRef]

Hennart, Jean-Francois. 1982. A Theory of Multinational Enterprise. Ann Arbor: University of Michigan Press.

IMF. 2009. Balance of Payments and International Investment Position Manual, 6th ed. Washington: IMF.

Ivus, Olena, Walter G. Park, and Kamal Saggi. 2017. Patent protection and the composition of multinational activity: Evidence from US multinational firms. Journal of International Business Studies 48: 808-36. [CrossRef]

Jude, Cristina. 2016. Technology spillovers from FDI. Evidence on the intensity of different spillover channels. The World Economy 39: 1947-73. [CrossRef]

Kathuria, Vinish. 2000. Productivity spillovers from technology transfer to Indian manufacturing firms. Journal of International Development 12: 343-69. [CrossRef]

Keller, Wolfgang. 2004. International technology diffusion. Journal of Economic Literature 42: 752-82. [CrossRef]

Kim, Linsu. 2001. The dynamics of technological learning in industrialisation. International Social Science Journal 53: 297-308. [CrossRef]

Kokko, Ari. 1996. Productivity spillovers from competition between local firms and foreign affiliates. Journal of International Development: The Journal of the Development Studies Association 8: 517-30. [CrossRef]

Le, Hoi Quoc, and Richard Pomfret. 2011. Technology spillovers from foreign direct investment in Vietnam: Horizontal or vertical spillovers? Journal of the Asia Pacific Economy 16: 183-201. [CrossRef]

Mauri, Alfredo J., Sangcheol Song, and Joao Neiva de Figueiredo. 2016. US MNE firm-specific advantages and inter-regional expansion. In Academy of Management Proceedings. Briarcliff Manor: Academy of Management, p. 10543.

Mebratie, Anagaw Derseh, and Peter A. G. van Bergeijk. 2013. Firm heterogeneity and development: A meta-analysis of FDI productivity spillovers. The Journal of International Trade Economic Development 22: 53-74. [CrossRef]

Meyer, Klaus E., and Evis Sinani. 2009. When and where does foreign direct investment generate positive spillovers? A meta-analysis. Journal of International Business Studies 40: 1075-94. [CrossRef]

Narula, Rajneesh, and Anabel Marin. 2003. FDI spillovers, Absorptive Capacities and Human Capital Development: Evidence from Argentina. Maastricht: MERIT, Maastricht Economic Research Institute on Innovation and Technology.

Orlic, Edvard, Iraj Hashi, and Mehtap Hisarciklilar. 2018. Cross sectoral FDI spillovers and their impact on manufacturing productivity. International Business Review 27: 777-96. [CrossRef]

Peteraf, Margaret A. 1993. The cornerstones of competitive advantage: A resource-based view. Strategic Management Journal 14: 179-91. [CrossRef]

Rhoades, Stephen A. 1993. The herfindahl-hirschman index. Federal Reserve Bulletin 79: 188.

Romer, Paul M. 1990. Endogenous technological change. Journal of Political Economy 98: 71-102. [CrossRef]

Rugman, Alan M. 1981. Inside the Multinationals: The Economics of International Markets. New York: Colombia University Press.

Rugman, Alan M. 2006. Internalization as a general theory of foreign direct investment. In Inside the Multinationals 25th Anniversary Edition. London: Palgrave Macmillan, pp. 18-33.

Sönmez, Alper. 2013. Multinational Companies, Knowledge and Technology Transfer: Turkey's Automotive Industry in Focus. Berlin: Springer Science \& Business Media.

Tabachnick, Barbara G., and Linda S. Fidell. 2007. Using Multivariate Statistics. Boston: Pearson.

Thi Ngoc Huynh, Hien, Phuong V. Nguyen, and Khoa T. Tran. 2018. Internationalization and Performance of Vietnamese Manufacturing Firms: Does Organizational Slack Matter? Administrative Sciences 8: 64. [CrossRef]

Tian, Xiaowen. 2007. Accounting for sources of FDI technology spillovers: Evidence from China. Journal of International Business Studies 38: 147-59. [CrossRef] 
UNCTAD. 2010. World Investment Report: Investing in a Low Carbon Economy. Geneva: United Nations.

UNCTAD. 2018. World Investment Report: Investment and New Industrial Policies. Geneva: United Nations.

Verbeke, Alain. 2013. International Business Strategy. Cambridge: Cambridge University Press.

Vernon, Raymond. 1977. Storm over the multinationals: Problems and prospects. Foreign Affairs 55: $243-62$. [CrossRef]

Wang, Jian-Ye, and Magnus Blomström. 1992. Foreign investment and technology transfer: A simple model. European Economic Review 36: 137-55. [CrossRef]

$\mathrm{Xu}$, Bin. 2000. Multinational enterprises, technology diffusion, and host country productivity growth. Journal of Development Economics 62: 477-93. [CrossRef]

Zhang, Yan, Haiyang Li, Yu Li, and Li-An Zhou. 2010. FDI spillovers in an emerging market: The role of foreign firms' country origin diversity and domestic firms' absorptive capacity. Strategic Management Journal 31: 969-89. [CrossRef]

(C) 2019 by the authors. Licensee MDPI, Basel, Switzerland. This article is an open access article distributed under the terms and conditions of the Creative Commons Attribution (CC BY) license (http://creativecommons.org/licenses/by/4.0/). 